(C) The Author(s), 2021. Published by Cambridge University Press. This is an Open Access article, distributed under the terms of the Creative Commons Attribution-NonCommercial-NoDerivatives licence (http://creativecommons.org/licenses/by-nc-nd/4.0/), which permits non-commercial re-use, distribution, and reproduction in any medium, provided the original work is unaltered and is properly cited. The written permission of Cambridge University Press must be obtained for commercial re-use or in order to create a derivative work.

\title{
A NEW SOLUTION CONCERNING CHOICE-OF-LAW FOR THE ASSIGNMENT OF DEBTS
}

\author{
Alison $\mathrm{XU}^{*}$ (1)
}

\begin{abstract}
This article explores a solution to the choice-of-law issues concerning both voluntary and involuntary assignments arising in a domestic forum. The focus is on English private international law rules relating to cross-border assignments. A distinction is made between primary and extended parties as the foundation for choice-of-law analysis. Drawing on insights from the distinction of the use value and exchange value of debts found in economics, this article proposes a new analytical framework for choice-of-law based on a modified choice-of-law theory of interest-analysis.
\end{abstract}

Keywords: private international law, choice-of-law, assignment of debts, lex situs, lex concursus, interest-analysis, third-party effects.

\section{INTRODUCTION}

In recent decades, debts have become an increasingly valuable trading commodity in the global financial market. ${ }^{1}$ The law of assignment prescribes the means by which debts are transferred, and covers important transactions such as factoring, asset-based lending, forfaiting, project financing, etc. The international nature of the debt market gives rise to a crucial point of private international law: the need to identify the national legal regime applicable to a particular cross-border assignment. Existing private international law rules do not provide a clear and satisfactory solution, resulting in uncertainty for parties to an international assignment. This article explores a simpler analytical framework for choice-of-law issues concerning international assignments arising in a domestic forum, with a view to increasing legal certainty for participating parties and removing barriers to cross-border

* Assistant Professor, Waseda Institute for Advanced Study, Waseda University, alisonxu@ aoni.waseda.jp. The author would like to thank Gerard McCormack and Sarah Brown for their critiques that helped shaping this article, Andrew Dickinson as well as panel participants for the first Conflict of Laws trial section of the 2017 Society of Legal Scholars Conference where an earlier draft was presented, two anonymous reviewers for their valuable comments and the journal for wonderful editorial support. All errors remain the author's own responsibility.

1 The estimated outstanding amount of international debt securities could exceed 20 trillion USD by the end of September 2020 (see Bank for International Settlements, 'BIS Quarterly Review' (2020) <https://www.bis.org/publ/qtrpdf/r_qt2009.pdf>). 
investments. To this end, this section explains, first, why the assignment of debts is generally considered a difficult topic in domestic private international law; second, why current international and regional efforts on harmonising rules still have their own constraints; and finally, why there is a focus on English private international law.

The choice-of-law for the assignment of debts is one of, if not the, most complex problems in private international law ${ }^{2}$ for three main reasons. ${ }^{3}$ First, an assignment can create complicated legal relationships that are treated differently in substantive national laws. ${ }^{4}$ The key issues include whether an assignment is to be regarded as being of a merely contractual or of a hybrid nature, involving both contractual and proprietary aspects; ${ }^{5}$ the steps parties should follow to validly conclude an assignment; whether an assignment has third-party effects and, if so, to what extent. ${ }^{6}$ Second, questions are raised regarding their characterisation: whether an international assignment raises any proprietary questions and, if so, which aspects can be classified as proprietary. Finally, and depending on the outcome of the characterisation, the applicable law is not always easy to determine because which choice-of-law doctrine ought to be applied remains controversial, especially for third-party issues. ${ }^{7}$

These difficulties have resulted in national private international law rules concerning cross-border assignments not always being clarified or even developed. As a result, parties involved in international assignments are often required to comply with multiple national legal requirements due to the lack of legal certainty, thus incurring increased transaction costs. Leaving such issues entirely to domestic private international law rules impedes the development of the global debt market and obstructs international trade more

2 See JM Carruthers, The Transfer of Property in the Conflict of Laws (Oxford University Press 2005) 145.

3 Additionally, see M Smith and N Leslie, The Law of Assignment (3rd edn, Oxford University Press 2018) ch 2; A Briggs, The Conflict of Laws (3rd edn, Oxford University Press 2013) ch 7; J Fawcett, J Harris and M Bridge, International Sale of Goods in the Conflict of Laws (Oxford University Press 2005) ch 19.

${ }^{4}$ The British Institute of International and Comparative Law (BIICL) published a Study Report that detailed national differences among 12 EU Member States' domestic laws in their substantive and conflict of laws treatments for the question of assignment: BIICL, Study on the Question of Effectiveness of an Assignment or Subrogation of a Claim against Third Parties and the Priority of the Assigned or Subrogated Claim over a Right of Another Person, Final Report (2014) 168-365.

5 See HLE Verhagen and S van Dongen, 'Cross-Border Assignments under Rome I' (2010) 6 J Priv Int L 2-3; A Flessner and H Verhagen, Assignment in European Private International Law: Claims as Property and the European Commission's 'Rome I Proposal' (Sellier European Law Publishers 2006) 10-12, 22-36.

${ }^{6}$ The phrase 'third-party' could give rise to confusion, as national laws may prescribe different meanings for the term (see Verhagen and van Dongen (n 5) 6-11). For an analysis of the restricted interpretation of the term 'third-party' as employed in EU instruments, see TC Hartley, 'Choice of Law regarding the Voluntary Assignment of Contractual Obligations under the Rome I Regulation' (2011) 60 ICLQ 38-9.

7 Possible solutions being discussed include the law of the contract between the assignor and the assignee, the law of the assigned debt, and the law of the assignor's habitual residence (see Final Report (n 4) 384-404). 
generally. ${ }^{8}$ Therefore, the international community has long searched for ways to achieve legal harmonisation in this area. Attempts to harmonise substantive law have not been successful so far, ${ }^{9}$ but regional unification of private international law rules has thrived, especially in the European Union (EU). The first stage of harmonisation is found in the 2008 Rome I Regulation, Article 14 of which effectively unifies the choice-of-law rules applicable to a single voluntary assignment. ${ }^{10}$ Since 2018 , EU legislators have been working on a new regulation concerning the law applicable to the third-party effects of assignments of claims, ${ }^{11}$ which is intended to harmonise the choice-of-law rules governing the remaining issues of competing assignments not covered by Rome I. ${ }^{12}$ This will eventually lead to the adoption of a general approach to the choice-of-law rules for cross-border assignments in the EU, ${ }^{13}$ and it is likely that they will be adopted in the near future. ${ }^{14}$ Both Rome I and the new proposal have been criticised. ${ }^{15}$ However, they remain the most progressive regional legal harmonisation initiatives.

While EU legislators strive to establish unified rules, the United Kingdom (UK) has expressly chosen not to opt in to the proposal, as doing so would

8 See UNGA Convention on the Assignment of Receivables in International Trade (adopted 12 December 2001, not yet in force) Preamble.

9 Relevant instruments include UNGA Convention on the Assignment of Receivables in International Trade, not yet in force; UNIDROIT Convention on International Factoring (adopted 28 May 1988, entered into force 1 May 1995), currently with 9 contracting States; and UNIDROIT Convention on International Financial Leasing (adopted 28 May 1988, entered into force 1 May 1995), with 11 contracting States. None of these instruments has taken effect in the UK. Another representative soft law instrument is the UNCITRAL Legislative Guide on Secured Transactions (United Nations 2010).

${ }^{10}$ Council Regulation (EC) No 593/2008 on the law applicable to contractual obligations (Rome I) [2008] OJ L177/6. It is improved from the earlier version of the Rome Convention with a few key clarifications on the relevant provisions, notably art 12, 1980 Rome Convention on the law applicable to contractual obligations (consolidated version) [1998] OJ C27/34.

11 In 2018, the European Commission submitted a 'Proposal for a Regulation on the law applicable to the third-party effects of assignments of claims' COM(2018) 96 final (hereinafter '2018 Proposal'). The first reading position was adopted by the European Parliament on 13 February 2019, Texts Adopted for the Proposal for a regulation on the law applicable to the third-party effects of assignments of claims [2020] OJ C449/41.

12 Commission Staff Working Document Impact Assessment SWD(2018) 52 final, 13-14.

13 See Commission Staff Working Document Executive Summary of the Impact Assessment $\operatorname{SWD}(2018) 53$ final.

14 The proposal was discussed at the ECOFIN Council meeting held in March 2020, where the presidency stressed 'the intention to work towards reaching a general approach on the proposal' (see Annex 'State of play of the Proposal for a Regulation on assignments of claims', Information from the Presidency on the Proposal ST 6664/20 INIT). A progress report was presented at the Permanent Representatives Committee on 26 November 2020, being the latest discussion on the Proposal (see Council Document ST 13122/20 COR 1).

${ }^{15}$ There has been rich discussion on the Rome regime, eg, THD Struycken, 'The Proprietary Aspects of International Assignment of Debts and the Rome Convention, Article 12' [1998] LMCLQ 345; M Bridge, 'The Proprietary Aspects of Assignment and Choice of Law' (2009) 125 LQR 671; R Goode, 'The Assignment of Pure Intangibles in the Conflict of Laws' [2015] LMCLQ 289. For a recent article commenting on the 2018 Proposal, see H Labonté, 'Third-Party Effects of the Assignment of Claims: New Momentum from the Commission's Capital Markets Union Action Plan and the Commission's 2018 Proposal' (2018) 14 J Priv Int L 319. 
'have significant unintended consequences for financial services market practices in the UK' ${ }^{16}$ This decision was very likely made, in part, due to the complexities of Brexit and because English authors were inclined towards a solution that differed from the EU's approach. ${ }^{17}$ The situation of the UK is not unusual for States that do not have access to harmonised rules. While regional harmonisation progresses incrementally, providing piecemeal solutions with an overarching objective, an oft-neglected option is that of a more general and holistic approach, examining all situations facing a domestic court.

This article offers a fresh account of the choice-of-law for the assignment of debts drawing on insights from an economics perspective and interest-analysis theory. It argues that different conflicting interests underlie specific legal disputes and that a nuanced analysis may render some of the many issues related to the perceived choice-of-law conundrum less overwhelming. For this purpose, the article examines English private international law rules dealing with both voluntary and involuntary assignments as a case study. Current relevant EU regulations are also considered. The article has four sections. First, it revisits the abstract legal structure of assignments, distinguishing between primary and extended parties as the foundation for choice-of-law analysis. Second, it considers the English choice-of-law rules governing voluntary assignments. Third, it examines choice-of-law issues related to involuntary assignments in the UK, namely, insolvency proceedings and third-party debt orders. Finally, drawing insights from the distinction found in economics between the use value and exchange value of debts, the article proposes a new analytical framework based on a modified choice-of-law theory of interest-analysis. It maintains that a proper conflict of laws analysis is the key to a logically coherent solution and that the question of choice-of-law can be resolved in a straightforward manner.

\section{THE LEGAL STRUCTURE OF ASSIGNMENTS}

For private international law purposes, debts are classified and dealt with as pure intangibles. ${ }^{18}$ The legal concept of assignment is used to describe how the rights to direct the disposition of debts can be transferred. ${ }^{19}$ An assigned debt is essentially a

16 John Glen MP, the Economic Secretary to the Treasury, made the official statement on 9 July 2018: J Glen, 'JHA opt in decision - law applicable to the third-party effects of assignment of claims: Written statement' $(2018)<$ https://questions-statements.parliament.uk/written-statements/detail/ 2018-07-09/HCWS836>.

17 For example, the Financial Law Committee of the City of London Law Society (CLLS) published a document explaining its opinions on the earlier version of the 2018 Proposal: 'Proposed EU Regulation on law applicable to the third party effects of assignment of claims Why the UK should opt-out and work to get this proposal changed or scrapped' $<$ https://www. citysolicitors.org.uk/storage/2018/05/Proposed-EU-Regulation-on-law-applicable-to-the-thirdparty-effects-of-assignment-of-claims-24-05-18.pdf $>$. The committee listed 14 substantive issues associated with the proposal.

18 Pure intangibles are mere rights of action that lack physical existence by nature (see M Bridge, Personal Property Law (4th edn, Oxford University Press 2015) 15-16).

19 The concept of assignment should be distinguished from contract novation and subrogation, both of which fall outside the scope of this article. 
personal right against the debtor, but the way it is assigned mirrors the transfer of a piece of property. ${ }^{20}$ An assignment can take place either voluntarily, by contract, ${ }^{21}$ or involuntarily, by the operation of law, under domestic insolvency law or procedural rules governing third-party debt orders. ${ }^{22}$

The legal relationships concerning the assignment of debts can become complicated. A distinction is made between primary parties, who are directly involved in a particular assignment, and extended parties, who become involved when the legal effects of an earlier assignment are affected by a subsequent assignment. ${ }^{23}$

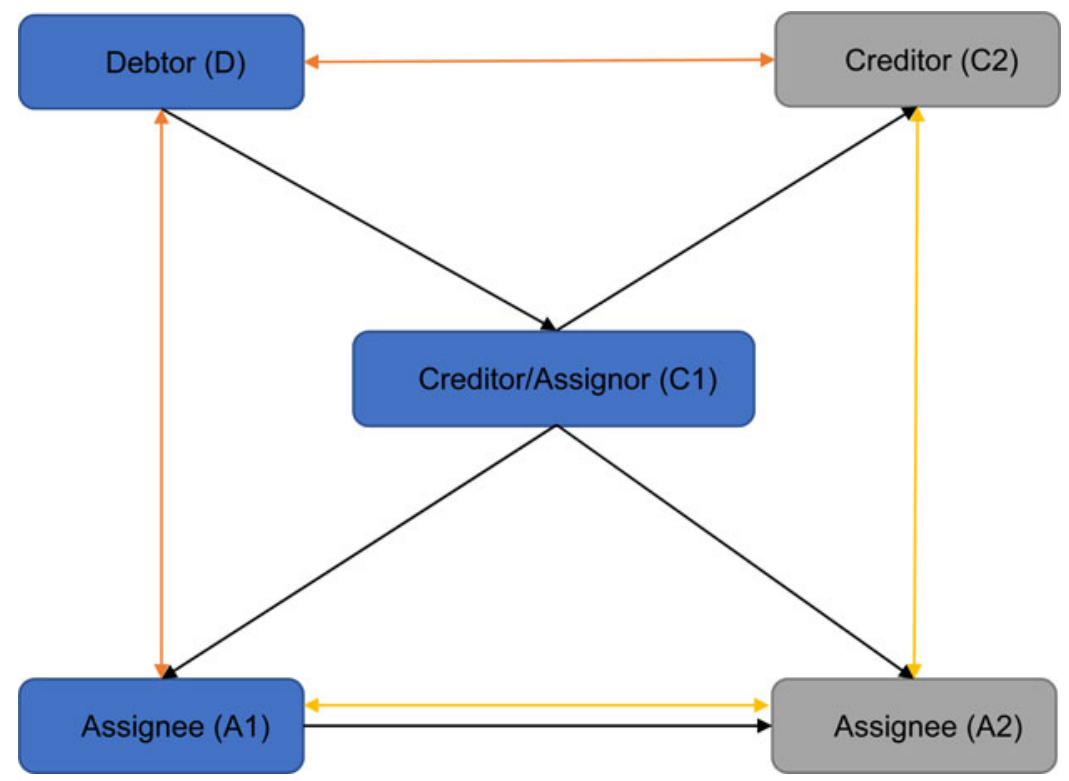

FIgURE 1. Legal relationships in an assignment ${ }^{24}$

Primary Parties: A1, D, C1.Extended parties: C2, A2. C2: If C1 becomes insolvent, $\mathrm{C} 2$ refers to the insolvency administrators. $\mathrm{C} 2$ : In the case of a thirdparty debt order, $\mathrm{C} 2$ refers to the judgment creditor. A2: The assignee under a subsequent voluntary assignment.

20 Bridge (n 18) 229-30.

21 Voluntary assignment can be contractual or non-contractual, according to national contract law. For instance, an assignment as an outright gift is voluntary but non-contractual in the common law (see Carruthers (n 2) 148-50).

22 The common law recognises other ways by which intangibles can be transferred, for example, equitable assignment and statutory assignment, neither of which will be addressed here. See Bridge (n 18) 233-50; Smith and Leslie (n 3) chs 14-16.

23 A similar classification was adopted in an outstanding paper published in the ICLQ ten years ago (see Hartley (n 6) 30-2). Professor Janeen Carruthers adopts the distinction of original-parties and remote-parties disputes in her work (see Carruthers (n 2) 160-3).

24 To avoid an overcomplicated diagram, two lines are missing from the figure. One refers to the claim that $\mathrm{A} 2$ can also make against $\mathrm{D}$, as it is essentially the same as what would happen between 


\section{A. Primary Parties}

Primary parties are three actors: 'debtor or obligor' (D), 'creditor (assignor)' (C1) and 'assignee' (A1). All three primary parties are needed for an assignment. The assigned debts are monetary obligations that $\mathrm{D}$ owes to $\mathrm{C} 1$. By way of an assignment, A1 is assigned only the benefits that $\mathrm{C} 1$ has against $\mathrm{D}$ but not the obligations. A voluntary assignment takes effect under an arrangement concluded autonomously between $\mathrm{C} 1$ and $\mathrm{A} 1$, whereas in an involuntary assignment, A1 acquires relevant entitlements based on the operation of law. In the latter case, A1 refers to either the insolvency representatives of $\mathrm{C} 1$ in an insolvency proceeding or the judgment creditor of $\mathrm{C} 1$ in a third-party debt order.

The choice-of-law question concerning primary parties is twofold. First, what law governs the assignment, and second, what are the effects of applying that law? The latter question raises further complexities when determining the status of extended parties. For example, as between A1 and D, following an effective assignment A1 will generally have the right to recover the assigned sum directly from $\mathrm{D}$, and $\mathrm{D}$ should obtain a good discharge by repaying A1. ${ }^{25}$ However, whether $\mathrm{C} 1$ loses the right to receive the assigned debt depends on national law. In a jurisdiction where an assignment is viewed as involving the disposition of property rights, $\mathrm{C} 1$ 's direct right to the debt against $\mathrm{D}$ will probably be regarded as being extinguished as a result of the assignment. However, if an assignment is viewed as a contractual agreement with no immediate consequence for property rights, C1's existing rights to the debt would not necessarily cease to exist upon an assignment.

\section{B. Extended Parties}

Extended or third parties generally refer to those non-primary parties whose entitlements with respect to the debt could be affected by an earlier assignment. The phrase 'third parties' may cause confusion, as the debtor may also be considered a third party to an assignment concluded by contract. Since the third-party debt order is also discussed in this article, the term 'extended parties' is preferred. Questions concerning the position of extended parties are more problematic and challenging. Unlike primary parties, extended parties are not necessarily concerned in a cross-border assignment dispute but are concerned where there is a subsequent assignment. This may involve either a subsequent involuntary assignment, eg, $\mathrm{C} 1$ becomes insolvent after assigning the debt to A1, or two voluntary assignments, eg, $\mathrm{C} 1$ assigns the same debt to A1 and A2. C2 and A2, illustrated in Figure 1, have dual positions as the

\footnotetext{
$\mathrm{A} 1$ and $\mathrm{D}$. The other refers to a competing claim between $\mathrm{C} 2$ and $\mathrm{A} 1$, which is the same as that between $\mathrm{C} 2$ and $\mathrm{A} 2$.

${ }^{25}$ For example, whether a notice in writing is required (see Section 136 of Law of Property Act 1925).
} 
primary parties to the second assignment and extended parties to the first assignment. The focus here is on their position as extended parties.

$\mathrm{C} 2$ refers to the assignee of a subsequent involuntary assignment, for example the liquidators or administrators should $\mathrm{C} 1$ become insolvent or $\mathrm{C} 1$ 's judgment creditors in a third-party debt order. First, when $\mathrm{C} 1$ becomes insolvent, $\mathrm{C} 2$ will be assigned the rights to manage the debts under the operation of national insolvency laws. Suppose A1 and C1 have concluded a voluntary assignment with respect to the same debts; $\mathrm{A} 1$ and $\mathrm{C} 2$ could be involved in a dispute concerning whether the debts have been transferred out of $\mathrm{C} 1$ 's insolvent estate. The question then arises of whether the effectiveness of an involuntary assignment could override the effects of a voluntary assignment. Second, C2, as the judgment creditor, might obtain a third-party debt, or attachment, order against $\mathrm{D}$ on the grounds that $\mathrm{C} 1$ has a pre-existing monetary obligation to $\mathrm{C} 2$. As a result, $\mathrm{C} 2$ should be able to demand repayment from $\mathrm{D}$. However, if $\mathrm{C} 1$ had previously assigned the debts to $\mathrm{A} 1$, there might be a question of priority between the competing claims of $\mathrm{C} 2$ and $\mathrm{A} 1$ against the debts.

A2, on the other hand, is the assignee of a subsequent assignment that is voluntarily made. This can happen either when a debt is assigned more than once by the same assignor, $\mathrm{C} 1$, or when a debt is assigned consecutively by $\mathrm{C} 1$ and then by $\mathrm{A} 1$. This situation gives rise to an issue of priority between voluntary assignees $\mathrm{A} 1$ and $\mathrm{A} 2$.

\section{Three-Tier Legal Relationships and the Choice-of-Law}

The legal relationships concerning assignments have three tiers. First, the basic unit constituting an assignment includes a debtor (D), an assignee (A1), and an assignor/creditor $(\mathrm{C} 1)$, ie, the primary parties. $\mathrm{D}$ and $\mathrm{C} 1$ are directly connected via a legal relationship under which the debts are generated. A new legal relationship is formed between $\mathrm{C} 1$ and $\mathrm{A} 1$ under the assignment. There is an indirect connection between $\mathrm{D}$ and $\mathrm{A} 1$, since the assignment purports to allow a direct claim by $\mathrm{A} 1$ against $\mathrm{D}$. The second tier refers to a situation in which $\mathrm{C} 2$ would be in a position to compete with A1 concerning an entitlement against the debts under an involuntary assignment. The third tier is where debts have been voluntarily assigned twice, giving rise to the question of priority between A1 and A2.

In theory, determining the applicable law should be fairly straightforward between those who have direct legal relationships: the relationship between $\mathrm{D}$ and $\mathrm{C} 1$ should be governed by the law governing the debts/creation of the debts, and the relationship between $\mathrm{C} 1$ and $\mathrm{A} 1$ should be governed by the law governing the assignment. However, the situation is not entirely clear with regard to indirect relations, for example, A1 and D, A1 and A2, and C2 and A1. This article argues that a sound solution for the choice-of-law should balance the interests of the different parties. To do so, the reasonable expectations of the parties concerned should first be outlined: 
- D should not be exposed to excessive liabilities and not have to pay more than the sum owed.

- C1 should be able to benefit from trading debts internationally, provided this is not misused.

- A1/A2 should have a reasonable expectation of being able to direct the disposition of debts conferred by the voluntary agreement. This not only includes the right to make a direct claim against $\mathrm{D}$ for debt recovery but also to make another assignment.

- $\mathrm{C} 2$ should aim to preserve the debts as part of $\mathrm{C} 1$ 's assets and to receive repayments.

Two different sets of considerations arise for the various parties. The primary focus of both D and C2 is on debt settlements, whereas both $\mathrm{C} 1$ and A1/A2 are more concerned with debt transactions. The first concerns fairness, while the second concerns economic efficiency. Thus, when balancing the relevant interests of the different parties, three choice-of-law doctrines need to be considered: the law governing the debts, which sets out the basic features of these debts; the law of the situs, which plays a role in safeguarding the interests of the debtor; and the law governing the assignment, which sets out the rights of the parties to a particular assignment. As will be illustrated, the suitability of each doctrine depends on the circumstances of each dispute, and a distinction should be drawn between voluntary and involuntary assignments for private international law purposes.

\section{THE CHOICE-OF-LAW AND VOLUNTARY ASSIGNMENTS}

In general, English private international law ${ }^{26}$ rules governing cross-border assignments have developed slowly. This is partly because receivables financing has only recently become economically significant. This is also because English courts may construe assignment cases through a substantive law approach instead of using private international law. ${ }^{27}$ Even when a matter is considered in private international law, the issue might be resolved through a straightforward contractual choice-of-law analysis and without developing a more general approach to assignments. ${ }^{28}$ At present, common law only offers clear solutions to disputes concerning primary parties to a voluntary assignment and remains silent on competing assignments affecting extended parties. This section first considers the question of characterisation, particularly the different approaches adopted in substantive law and in conflict of laws; it then considers the impact of a significant case, Raiffeisen Zentralbank Österreich AG v Five Star General Trading LLC and article.

${ }^{26}$ The terms 'private international law' and 'conflict of laws' are used interchangeably in this

${ }^{27}$ See Lord Collins et al (eds), Dicey, Morris and Collins On the Conflict of Laws (15th edn, Sweet \& Maxwell 2012) para 22-025.

${ }_{28}$ In many cases, it is also dependent on the way a question is phrased (see Briggs (n 3$)$ 307-8). 
others ${ }^{29}$ finally, it considers the current English choice-of-law approach to voluntary assignments.

\section{A. Characterising the Contractual and Proprietary Aspects}

In common law, assignments are regarded as a hybrid concept involving both contractual and proprietary aspects. In Fitzroy $v$ Cave, it was noted that 'a debt must be regarded as a piece of property capable of legal assignment in the same sense as a bale of goods'. ${ }^{30}$ It acknowledges that a debt, by itself, is only contractual and personal, but an assignment adds a third-party dimension, which 'can convert a personal right into a proprietary right' ${ }^{31}$ Therefore, conceptually, there becomes a proprietary relationship between the assignor and the assignee, similar to that between buyers and sellers in the sale of goods. Assignments confer rights to the assignee, which are erga omnes.

The question here is whether a proprietary understanding of assignments, as found in substantive law, should also be applicable to the approach in private international law. If so, a judge needs to determine whether a claim is contractual or proprietary in nature to identify the choice-of-law doctrine applicable, and this is not always an easy task. This approach has received academic support. Notably, Professor Michael Bridge suggested that the following should be viewed as proprietary:

First, the effectiveness of a transfer or security granted of or in a debt as between assignor and assignee; secondly, the opposability of an assignee's right against execution creditors of the assignor; thirdly, the opposability of an assignee's rights against the liquidator or other insolvency representative of the assignor; and fourthly, priority between competing assignees and between an assignee and a third party asserting a competing claim to the debt or right in the hands of the assignor. ${ }^{32}$

Points 2-4 all refer to disputes arising from competing assignments and concern extended parties, in the example given above either A1 and C2 or A1 and A2. However, if a dispute concerns only primary parties, which aspects should then be classified as proprietary? How can proprietary aspects be distinguished from contractual aspects?

The key point arising from a proprietary understanding is that the arrangement between assignor $\mathrm{C} 1$ and assignee $\mathrm{A} 1$, though contractually concluded, results in the disposition of the property, regarded as the 'most important feature of assignment'. ${ }^{33}$ The contractual elements of the

\footnotetext{
29 The case contains two stages, including the first instance trial, Raiffeisen Zentralbank Österreich AG v Five Star General Trading LLC and others [2000] CLC 1359 (QB), (Five Star (No 1)); and the appeal trial, Raiffeisen Zentralbank Österreich AG v Five Star General Trading LLC and others [2001] EWCA Civ 68, [2001] QB 825, (Five Star (No 2)).

[0 [1905] 2 KB 364, 373 (Cozens-Hardy LJ).

32 Bridge (n 15) 687. 
relationship between $\mathrm{A} 1$ and $\mathrm{C} 1$ are more easily ascertainable, for example, the terms of the contract of assignment and the remedies available for breach, but it is not entirely clear which issues are proprietary in nature. Arguably, if the main purpose of an assignment is to divest the assignor of their interest in the debt,,${ }^{34} \mathrm{a}$ requirement that notice should be given to the debtor to 'perfect' an assignment could be considered 'proprietary'. ${ }^{35}$ Such a view has not yet been clearly stated, however.

If, on its facts, a case is considered to only concern the relationship between $\mathrm{C} 1$ and $\mathrm{A} 1$, a contractual understanding of the assignment is being taken by the Court. Consequently, it is not necessary to consider the difference between contractual and proprietary aspects of the case, which greatly reduces the level of difficulty regarding the choice-of-law. The leading authority is Raiffeisen Zentralbank Österreich AGv Five Star General Trading LLC and others (Five Star (No 2)), ${ }^{36}$ which was decided based on the 1980 Rome Convention. ${ }^{37}$

\section{B. Five Star (No 2)}

The facts are set out for illustrative purposes. The case could have given rise to a discussion of competing assignments, but the Court carefully avoided doing so and instead focused only on a single assignment.

The ship, Mount I, was involved in a collision in the Malacca Strait during her voyage to India for scrapping. Before the voyage, the shipowners, Five Star Trading LLC, obtained from their French insurers a marine insurance policy that was expressly governed by English law. Five Star later assigned the policy to an Austrian bank, RZB, as security when raising funds. The assignment was conducted by a deed that was also governed by English law. While a notice of the assignment was given to the French insurers in accordance with the formalities required by English law, such notice would not be binding on the insurers under French law. ${ }^{38}$ Mount I collided with another ship, ICL Vikraman, causing the latter to sink and lose her cargo. Mount I was impounded and later sold by a Malaysian court. At the time of the case, substantive liability for the collision was still being litigated in Malaysia. Fearing that the funds raised by the sale of the vessel would not be sufficient to cover their loss, the owners of cargo on board ICL Vikraman obtained from a French court five orders that served as 'preventive attachments ${ }^{\prime 39}$ against the French insurers with respect to the proceeds of the

\footnotetext{
34 See ibid 687.

35 See R Fentiman, 'Assignment and Rome I: Towards a Principled Solution' (2010) 4 LFMR 408 .

36 See Five Star (No 2) (n 29).

37 The content of the Rome Convention has been incorporated into English domestic law as Contracts (Applicable Law) Act 1990.

38 The French law requires that a notice should be conducted through a bailiff in order for it to be binding on the debtor. See Five Star (No 2) (n 29) [13]. 
insurance policy. Then, RZB, the assignee, initiated proceedings in an English court seeking four declarations concerning its rights to the proceeds of the insurance. Five Star, cargo owners, and French insurers were listed as defendants.

This case involves two assignments. The first was a voluntary assignment between the assignor, Five Star (C1), and the assignee, RZB (A1), and it affected the French insurers as the debtor (D). The second was an involuntary assignment in the form of the attachment orders authorised by the French court, as a result of which the cargo owners became the judgment creditor, C2. Both the primary and extended parties were present in the case, but, as the result shows, the issue of extended parties was successfully avoided. The level of complexity of an assignment case may depend largely on how smartly a claim is phrased.

The issue of characterisation was addressed by the court in two stages: first, whether the claims were proprietary or contractual in nature and, second, if the issue was contractual, whether it was sufficiently covered by Article 12 of the Rome Convention, which reads:

(1) The mutual obligations of assignor and assignee under a voluntary assignment of a right against another person ('the debtor') shall be governed by the law which under this Convention applies to the contract between the assignor and assignee; (2) The law governing the right to which the assignment relates shall determine its assignability, the relationship between the assignee and the debtor, the conditions under which the assignment can be invoked against the debtor and any question whether the debtor's obligations have been discharged. ${ }^{40}$

The court of first instance reviewed the nature of the four claims that were made by RZB (A1): (1) The relevant interests in the policy were effectively assigned by Five Star $(\mathrm{C} 1)$ to A1 according to English law. (2) $\mathrm{C} 1$ was divested of the interest in the policy as a result of the assignment. (3) A1 took the place of $\mathrm{C} 1$ and was entitled to receive payment from French insurers (D). (4) As a result, any payments from the policy should be made to A1. ${ }^{41}$ Based on a literal reading of these submissions, the court characterised issues (2) and (3) as being proprietary and (1) and (4) as being contractual. However, it then questioned whether it was appropriate for the nature of a dispute to 'depend merely on the way in which one phrases the relevant question'. ${ }^{42}$ A general point was also made concerning the difference between an assignment of intangibles and a transfer of goods ${ }^{43}$ that seemed to question whether any proprietary aspects were raised at all. The court concluded that the dispute was a contractual one and was covered by Article 12(2) of the Rome

401980 Rome Convention on the law applicable to contractual obligations (consolidated version) [1998] OJ C27/34.

43 'If it is relevant to consider title to such choses in action at all ... it is difficult, if not impossible, to divorce the concept of such title from the underlying contract which has created the chose in action in the first place' (ibid 1363). 
Convention. ${ }^{44}$ It found for the claimant and granted the declarations requested.

The cargo owners appealed on the grounds that the claims should be characterised as proprietary, arguing that French law should be applicable as the law of the situs of the debt. This would mean that the insurers (D) would not be bound by the assignment. The Court of Appeal first affirmed the general approach of characterising the issue as being contractual in nature but added that the factual complexity of this case required a more 'nuanced analysis' ${ }^{45}$ Following a chronological approach, Mance LJ rightly noted that two assignments were in dispute and that the court should determine whether RZB's (A1) rights were based on an effective voluntary assignment between $\mathrm{A} 1$ and $\mathrm{C} 1$ or on the basis that the first assignment prevailed over C2's claim based on the second assignment. ${ }^{46}$ The former depends on the validity of the voluntary assignment, while the latter concerns the priority of competing assignments affecting extended parties.

The court found that since both RZB (A1) and the cargo owners (C2) had framed their submissions around the validity of the first assignment, ${ }^{47}$ which the court deemed essentially contractual, the case was not about competing assignments. In applying Article 12(2) of the Rome Convention, English law should be applied as the law chosen by the assignor and the assignee when determining the validity of the assignment. RZB was awarded the declarations it sought, and the appeal was dismissed. Unfortunately, the court did not take the opportunity to clarify the choice-of-law rules governing competing assignments. In addition, the result could have been rather different, or at least more favourable to the cargo owners, if the cargo owners had asserted their priority over RZB's claim instead of stressing the invalidity of the first assignment.

\section{Characterisation Revisited}

Five Star (No 2) suggests that the court prefers a contractual understanding of the assignment, provided primary parties are those which are in dispute. This is the opposite of the proprietary understanding adopted in substantive law. Mance LJ made the following point about the inter partes relationships arising from voluntary assignments:

Under a contract which, from its outset, purports to confer on a third party a right of action, an issue whether the third party may enforce that right appears to me again essentially contractual. An issue whether, following an assignment, the obligor must pay the assignee rather than the assignor falls readily under the same contractual umbrella. ${ }^{48}$

44 ibid 1364.

47 See ibid [22].
${ }^{45}$ Five Star (No 2) (n 29) [20].

46 See ibid [20]-[21].
${ }^{48}$ Five Star (No 2) (n 29) [34]. 
At the time of the case, there was an ongoing debate concerning whether Article 12 of the Rome Convention was intended to cover any potential proprietary issues and, if so, by means of which of its subsections. ${ }^{49}$ Mance LJ took the view that the Rome Convention characterised issues among primary parties as merely contractual, regardless of whether a different position was taken in the relevant domestic legal system. ${ }^{50}$ In 2008, the Rome Convention was transposed into the Rome I Regulation, ${ }^{51}$ and what was previously Article 12 now takes the form of Article 14 of Rome I. ${ }^{52}$ The position taken in Five Star (No 2) should continue to be followed, as Recital 38 of Rome I clearly states that 'Article 14(1) also applies to the property aspects of an assignment, as between assignor and assignee, in legal orders where such aspects are treated separately from the aspects under the law of obligations'.

In fact, these two seemingly opposing views on assignments are not in serious conflict when primary parties are concerned. A proprietary approach recognises that conceptually, there is a property aspect of assignment, but its manifestation is mostly found when extended parties are concerned. If a legal dispute is only concerned with primary parties, which aspects need to be characterised as proprietary remains uncertain, but acknowledging its existence is important for being logically coherent with domestic law. A contractual approach, on the other hand, pragmatically disregards any legal effects of assignment on extended parties and focuses only on primary parties' rights and obligations under an assignment, which are in effect less disputed if deemed contractual. The latter is adopted in the Rome I regime, which does not deal with extended parties, offering a pragmatic solution whereby characterisation focuses on the factual situations to be addressed rather than the property/ contract divide. ${ }^{53}$ It helps reconcile different domestic views on assignment to achieve some level of international consensus. This approach also enables national courts to adopt an interpretation that has an international spirit, as they did in Five Star (No 2). ${ }^{54}$

49 See M Moshinsky, 'The Assignment of Debts in the Conflict of Laws' (1992) 108 LQR 591, 613-16; ME Koppenol-Laforce, 'The Property Aspects of an International Assignment and Article 12 Rome Convention' (1998) 45 NILR 132-6. $\quad 50$ See Five Star (No 2) (n 29) [48].

51 Reg (EC) 593/2008 [2008] OJ L177/6.

52 The new provision contained in the regulation has improved with better wording, although the drafting of recital 38 has received some criticism (see Hartley (n 6) 33).

53 For further explanation on the negotiation of Rome I, see A Møllmann, 'Security Assignment of Debts and the Conflict of Laws' [2011] LMCLQ 262, 272.

54 To construe an international instrument, "national courts must clearly strive to take a single, international or "autonomous" view of the concept of contractual obligations that is not blinkered by conceptions - such as perhaps consideration or even privity - that may be peculiar to their own countries. Further - and perhaps particularly so when the search is for an autonomous international view - the man-made concepts of contractual obligations and proprietary rights are neither so clear nor so inflexible that they may not receive shape from the subject matter and wording of the Convention itself' (Five Star (No 2) (n 29) [33]). It went even further to allow for a circulatory process of characterisation (see [29]). 


\section{The Choice-of-Law for Primary Parties}

Choice-of-law rules governing primary parties are quite straightforward. Article 14 of Rome $\mathrm{I}^{55}$ provides the following:

1. The relationship between assignor and assignee under a voluntary assignment or contractual subrogation of a claim against another person (the debtor) shall be governed by the law that applies to the contract between the assignor and assignee under this Regulation.

2. The law governing the assigned or subrogated claim shall determine its assignability, the relationship between the assignee and the debtor, the conditions under which the assignment or subrogation can be invoked against the debtor and whether the debtor's obligations have been discharged.

3. The concept of assignment in this Article includes outright transfers of claims, transfers of claims by way of security and pledges or other security rights over claims.

First, the relationship between $\mathrm{C} 1$ and $\mathrm{A} 1$ should be determined in accordance with the law governing their contract. The choice-of-law rules for contractual obligations should be determined in accordance with Articles 3 and 4 of Rome I, under which party autonomy serves as the primary principle. There is no need to distinguish proprietary and contractual aspects, should a case be covered by the Regulation. ${ }^{56}$ Second, the law of the underlying debt should be applied to determine the basic features of the debt, such as whether it can be transacted and the rights and obligations of $\mathrm{D}$. This ensures that $\mathrm{D}$ will not be exposed to additional burdens as a result of applying the law governing the assignment. The provision is comprehensive and covers most situations that are tentatively considered to be proprietary in common law. ${ }^{57}$ English private international law - as set out in Rule 135 of Dicey, Morris and Collinsadopts the same rules. ${ }^{58}$ In addition, Rule 135 takes a generic approach that encompasses extended parties, stating that 'the law with which the right (debts) assigned has its most significant connection' should be applicable. ${ }^{59}$ However, in the event of competing claims, there is little doctrinal guidance on how to determine the place with the most significant connection. ${ }^{60}$

To conclude, insofar as primary parties are concerned, choice-of-law rules can now be stated with certainty by referring to either the Rome I regime or to common law choice-of-law rules, and there is no need to characterise

55 As the impacts of Brexit on this regime remain uncertain at this stage, the following discussion will state the law as it currently stands.

56 Art 1 Rome I Regulation.

57 See Bridge (n 15) 688; P Rogerson, Collier's Conflict of Laws (4th edn, Cambridge University Press 2013) 403.

59 It is also preferred by other authors (see Carruthers (n 2) ch 9).

60 Dicey's editors later suggested three possible approaches: the proper law of the underlying obligation, the law governing the transactions between assignor and assignee, and the lex situs, as tentative solutions but expressed no preference (Dicey (n 27) para 24-053). 
interests as either proprietary or contractual for the purpose of private international law. The law governing the assignment should determine the mutual relationship between the assignor and the assignee, and the law of the underlying debt should determine the legal position with respect to the debtor.

\section{THE CHOICE-OF-LAW AND INVOLUNTARY ASSIGNMENTS}

Two types of proceedings, insolvency proceedings and third-party debt orders, can give rise to the legal effects of involuntary assignments in the UK. As involuntary assignment operates under domestic procedural rules, in theory, it should not present any difficulties regarding the choice-of-law, as the law of the forum, the lex fori, will normally be applicable. However, the situation becomes unclear when an involuntary assignment interacts with a voluntary assignment. For example, a court instituting insolvency proceedings may face questions concerning the effectiveness of a pre-existing voluntary assignment made against the debts of the insolvent estate, or a court may have to decide on the question of priority between a voluntary assignee and a judicial creditor who obtains a third-party debt order originating from a foreign court, as in the case of Five Star (No 2).

The underlying question is whether voluntary and involuntary assignments, by definition, protect different interests. On the one hand, a voluntary assignment facilitates debt transactions between $\mathrm{C} 1$ and $\mathrm{A} 1$, provided that no undue influence is exerted on D. On the other hand, an involuntary assignment mainly aims to secure C2's position as C1's creditor and to secure repayment from D because $\mathrm{C} 1$ is probably experiencing financial difficulties. In effect, the involuntary assignment restricts the ability of $\mathrm{C} 1$ to make voluntary assignments with respect to a debt.

The choice-of-law should, therefore, provide guidance regarding the law concerning whether a voluntary assignment is effective, notwithstanding the existence of an involuntary assignment. The position relating to insolvency proceedings is rather different from that relating to third-party debt orders. The former is strongly impacted by the process of EU legal harmonisation, whereas the latter remains largely a question of English domestic law. This section will examine the choice-of-law issues raised in these two different contexts.

\section{A. The Lex Concursus and Insolvency Proceedings}

Insolvency proceedings act as a general assignment under which $\mathrm{C} 1$ 's assets are subject to the control of $\mathrm{C} 2$, who represents the insolvency administrators. $\mathrm{C} 2$ has a dual position. First, $\mathrm{C} 2$ is conferred with the rights previously enjoyed by $\mathrm{C} 1$; this situation has been referred to as stepping into the shoes of the insolvent. ${ }^{61}$ In this regard, there is no material difference between C2's

61 'He (C2) is entitled to no more than what C (1) was entitled to' (Hartley (n 6) 38). 
position and that of A1 as a voluntary assignee. Second, the opening of insolvency proceeding confers on $\mathrm{C} 2$ the power to restrict C1's rights to dispose of assets and potentially to retrospectively override the legal effects of C1's actions on behalf of the general body of creditors. ${ }^{62}$ This section focuses on this second aspect of C2's position.

First, insolvency proceedings are, in general, governed by the law of the place where the proceedings are opened, the lex concursus. ${ }^{63}$ The rules are currently laid down by the EU Insolvency Regulation (Recast), ${ }^{64}$ Article 7 of which provides that the lex concursus should apply to a wide range of issues covering both procedural and substantive matters. ${ }^{65}$ As a general rule, after the opening of insolvency proceedings, the lex concursus should apply to determine whether $\mathrm{C} 1$ is capable of making any assignments with respect to debts that form part of the insolvent estate. ${ }^{66}$

Second, if a voluntary assignment has been made prior to the opening of insolvency proceedings, the EU regime treats debts located in EU Member States differently from those located in third States. If a debt is located in an EU Member State other than that in which the proceedings are opened, the opening of insolvency proceedings shall, in principle, not affect A1's assigned rights with respect to a debt, pursuant to Article 8(1) of the Recast. ${ }^{67}$ The location of a debt is determined in accordance with Article 2 of the Recast, ${ }^{68}$ this being the Member State where the debtor (D) has the centre of its main interests (COMI). ${ }^{69}$

Applying these rules, a pre-existing assignment will not, in the first instance, be affected by subsequent insolvency proceedings. Its effectiveness on primary parties should therefore be decided by choice-of-law rules governing voluntary assignments, on the basis of Article 14 of Rome I. Exceptionally, the insolvency administrators $(\mathrm{C} 2)$ can retrospectively challenge A1's rights under a previous voluntary assignment on the grounds that such an assignment is detrimental to the general body of creditors ${ }^{70}$ and provided that such an action is permitted by the lex concursus. ${ }^{71}$ However, this exception cannot be relied upon if, first, the

62 See ibid 38.

${ }^{63}$ Dicey (n 27) 30; P Torremans et al (eds), Cheshire, North \& Fawcett: Private International Law (15th edn, Oxford University Press 2017) 1319.

${ }^{64}$ Council Reg (EC) No 2015/848 on insolvency proceedings (recast) [2015] OJ L141/19. It is transposed from the earlier version, Council Regulation (EC) No 1346/2000 on insolvency proceedings [2000] OJ L160/1. $\quad{ }_{65}^{65}$ Art 7(2) Recast. $\quad{ }^{66}$ Section 2(b) of art 7 Recast.

${ }^{67}$ It states that 'The opening of insolvency proceedings shall not affect the rights in rem of creditors or third parties in respect of tangible or intangible, moveable or immoveable assets, ..., belonging to the debtor which are situated within the territory of another Member State at the time of the opening of proceedings.'

${ }^{68}$ Section 9 of art 2 Recast lists detailed rules to determine situs for different types of assets, specifically subsections (iii) on cash held in accounts with a credit institution and (viii) on general claims against third parties.

${ }^{69}$ Art 3(1) Recast provides that 'the centre of main interests shall be the place where the debtor conducts the administration of its interests on a regular basis and which is ascertainable by third parties'. $\quad{ }^{70}$ Art 8(4) Recast. $\quad{ }^{71}$ Section 2(m) of art 7(2) Recast. 
voluntary assignment is governed by the law of another Member State according to the Rome I regime ${ }^{72}$ and, second, the law of that Member State does not allow such challenges. ${ }^{73}$ In summary, if a voluntary assignment with respect to the debt is governed by the law of an EU Member State, the governing law should have determinative effects and not be challenged by the lex concursus.

The EU Regulation was enacted to reduce difficulties resulting from concurrent insolvency proceedings against the same assets. ${ }^{74}$ To this end, the rules of international jurisdiction are harmonised by applying the COMI solution to determine which national court is entitled to open the main proceedings. ${ }^{75}$ Courts from other Member States have only limited jurisdiction over insolvent debtors' (C1) assets located within their respective territories. ${ }^{76}$ This approach prevents national courts from delivering conflicting decisions against the same debtor (D) if an assignment has been concluded before the commencement of a proceeding. Unfortunately, this approach does not apply if a debt is situated in a third State, since Article 8 (1) of the Recast, according to which a pre-assignment will in principle not be affected by the opening of an insolvency proceeding, only applies to a debt situated in a Member State. It remains unclear which law should determine whether the effectiveness of a pre-existing voluntary assignment would survive an insolvency proceeding in such a situation. For example, if a debt is located in a non-EU country, such as China, while the main insolvency proceedings are opened in England, the matter becomes extremely complicated.

Consider first a case in which X (C1), an English company, is owed a debt by a French company, Y (D). Facing severe financial difficulties, $X$ is considering assigning the debt to $Z$ (A1), a Chinese company, to raise funds. The debt in question is regarded as a French debt, in accordance with the Recast.

- Situation 1: If, before concluding an assignment with $\mathrm{Z}, \mathrm{X}$ becomes insolvent and the proceedings are opened in England, then whether $\mathrm{X}$ can still make the assignment is to be decided by the law of the place where the proceeding is opened, lex concursus, English law.

- Situation 2: If X becomes insolvent in England after concluding the assignment with $\mathrm{Z}$, the assignment is not, prima facie, covered by the lex concursus pursuant to Article 8(1). Its effectiveness in binding the primary parties should be governed by the law determined under Article 14 of Rome I.

- Situation 3: Exceptionally, X's insolvency administrators (C2) can challenge the assignment under the lex concursus but only on the grounds that such a transaction is detrimental to the general body of X's creditors, by reference to Article 8(4) Recast, and provided that

72 This must be a Member State other than the one where the insolvency proceedings are opened.
73 Art 16 Recast. ${ }_{74}$ Recital 22 Recast. ${ }_{75}$ Art 3 Recast. ${ }_{76}$ Art 3(2) Recast. 
the relevant requirements in English law for this claim to succeed are satisfied. ${ }^{77}$

- Situation 4: Suppose the assignment is governed by French law according to Article 14 of Rome I. The claim made in Situation 3 will not be allowed if French domestic law does not allow challenges of this type, according to Article 16 Recast.

Now, consider slightly different facts. Z (D), the Chinese company, owes X (C1), the English company, a debt that is assigned to $\mathrm{Y}$ (A1), the French company. $\mathrm{X}$ has established an office and some assets in mainland China. The debt is probably considered a Chinese debt under these circumstances.

- Situation 5: If X later becomes insolvent in England, Article 8 Recast will no longer be applicable since the debt is situated in a third State. Whether the assignment survives the insolvency proceeding is dependent on national insolvency laws. The English court must consider whether domestic insolvency proceedings have universal effects over property situated overseas, the result of which varies depending on national laws. ${ }^{78}$ Furthermore, in the absence of a harmonised system of international jurisdiction relating to insolvency cases, a Chinese court may open insolvency proceedings against the English company, taking the debt as part of X's insolvency estate. Consequently, Z (D), as the debtor, would probably face a situation of being exposed to two simultaneous insolvency proceedings, while $\mathrm{Y}$ (A1) needs to contest its rights against $\mathrm{X}$ 's insolvency administrators (C2) in both foreign courts.

In conclusion, within the EU, internal cross-border assignments have a good chance of surviving subsequent insolvency proceedings since the law governing the assignment is decisive, but in other scenarios, the lex concursus could override the choice-of-law rules governing the effectiveness of a voluntary assignment.

\section{B. The Lex Situs and Third-Party Debt $\mathrm{Order}^{79}$}

The English third-party debt order, previously known as the 'garnishment' 80 proceeding, is a proprietary remedy that operates by means of an attachment

77 For example, rules on challenging transactions at an undervalue are provided in Section 4235, Insolvency Act 1986.

78 There are different approaches to the administration of cross-border insolvency. Theories, for example, universalism and territorialism, differ mainly on whether the opening of proceedings should have extraterritorial effects. See E Moustaira, International Insolvency Law: National Laws and International Texts (Springer 2019) 10-12.

79 For a general discussion, see Carruthers (n 2) 6.63-6; Cheshire (n 63) 1292-4.

80 Dicey (n 27) para 24-081. 
against the property of the judgment debtor. ${ }^{81}$ It enables the judgment creditor (C2) to recover a certain sum against the garnishee/third-party (D) who owes the judgment debtor (C1). Prior to applying for such an order, C2 must have obtained a court judgment — the County Court Judgment (CCJ)—setting out the debt that $\mathrm{C} 1$ owes. The French attachment orders that were at issue in Five Star (No 2) work in a similar way. This therefore represents another type of involuntary assignment, the effects of which depend on the operation of the law of the place where an order is granted. As the rules governing third-party debt orders constitute part of domestic procedural law, ${ }^{82}$ the lex fori should almost always apply. ${ }^{83}$ However, when a debt is located abroad, the court may consider the lex situs in determining whether to grant the order. ${ }^{84}$ The real risk of attaching a foreign debt is that it could put the third-party debtor in the adverse situation of facing excessive obligations because the court of the country in which the debtor resides could also exercise jurisdiction with respect to the same matter. Therefore, from a choice-of-law perspective, the extent to which the lex situs will be considered becomes a crucial issue for an English court.

In contrast to the situs determined under the EU regime, ${ }^{85}$ the situs of debts has a specific meaning in common law. This meaning was developed in a broader context, including not only choice-of-law matters but also jurisdictional $^{86}$ and administrative issues. ${ }^{87}$ The fact that a court needs to consider the situs of debts does not necessarily justify the application of the lex situs. ${ }^{88}$ Generally, the use of the lex situs is no longer considered an incontestable choice-of-law principle for assignments, voluntary and involuntary alike. ${ }^{89}$ However, it still plays a limited role in the case of third-party debt orders because there is a strong policy reason for the court to safeguard the interests of the debtor. For this reason, the lex situs remains an 'inconstant guide'. 90

81 Société Eram Shipping Co Ltd v Cie Internationale de Navigation and Others [2003] UKHL 30 [24] (Lord Bingham of Cornhill).

82 It is a general principle in private international law that foreign law is not relevant in deciding procedural aspects (see Briggs (n 3) 189). $\quad{ }^{83}$ Rule 19, Dicey (n 27) para 7R-001.

${ }^{84}$ General principles of recognition and enforcement of foreign judgments may also be relevant; see Cheshire (n 63) ch 16.

85 Art 2 Recast.

86 The law was developed mainly for the purpose of 'preventing conflicting jurisdictions' against the same person (The Attorney-General v Bouwens (1838) 4 Meeson and Welsby 171, 191 (Lord Abinger CB); 150 ER 1390 (Ex Ct)).

${ }^{87}$ For example, the situs might be considered in construing an English will or statute (see English Scottish and Australian Bank v Commissioners of Inland Revenue [1932] AC 238 (HL) 241 (Lord Buckmaster)).

${ }^{88}$ There are strong criticisms against the relevance of the lex situs rule in relation to intangible property (see PJ Rogerson, 'The Situs of Debts in the Conflict of Laws - Illogical, Unnecessary and Misleading' (1990) 49 CLJ 453-60).

89 Professor Roy Goode also noted that the application of lex situs in relation to pure intangibles is not 'axiomatic but needs justification' (Goode (n 15) 292).

90 Carruthers (n 2) 223. 
When determining the situs, the debtor's residence will be the key connecting factor. ${ }^{91}$ If residency cannot be ascertained ${ }^{92}$ or if the debtor has more than one residence, ${ }^{93}$ the situs will be the place where a debt is recoverable ${ }^{94}$ or where a debt is primarily payable. ${ }^{95}$ Essentially, the law of the situs is introduced to ensure that there is a substantial connection between the debtor and the debt. The lex situs, therefore, will always be a legal system with which the debtor is familiar, and it will usually be the place of the debtor's habitual residence.

Once the situs is determined, it is then necessary to determine whether the third-party debt is a foreign debt. ${ }^{96}$ The House of Lords established the general rule that an English court should not have jurisdiction over debts situated abroad. ${ }^{97}$ They did so because it was very unlikely that such an order, if granted, would be enforced in the court of the situs, thus undermining the very purpose of the order, this being the discharging of the debt. ${ }^{98}$ Furthermore, exercising jurisdiction over foreign debts may be inconsistent with the 'comity of nations', as it would interfere with assets under the control of a foreign jurisdiction. ${ }^{99}$ There is, however, an exception to this rule. If, under the lex situs, an English order is recognised as successfully discharging the liabilities of the third-party debtor to the judgment debtor, ${ }^{100}$ a court may exercise jurisdiction and grant an order with respect to a foreign debt. For this purpose, the court considers whether the law of the situs confers on the judgment creditor a 'straightforward and readily available means of enforcing its judgment against the assets of the judgment debtors'. ${ }^{101}$ If the answer is yes, the court may have no good reason to decline jurisdiction.

Once the first hurdle is cleared, the situation becomes more complex if the court has to determine the priority between a claim under a voluntary

91 See Taurus Petroleum Limited v State Oil Marketing Company of the Ministry of Oil, Republic of Iraq [2017] UKSC 64 [31].

92 In re Banque Des Marchands De Moscou (Koupetschesky) (No 2) [1954] 1 WLR 1108 (Ch) 1115 (Maugham J).

93 If the debtor has only one residence, the debtor's residence test prevails over the place of enforcement (see Kwok Chi Leung Karl v Commissioner of Estate Duty [1988] 1 WLR 1035 (PC) 1042 (Lord Oliver of Aylmerton)).

94 New York Life Insurance Company v Public Trustee [1924] 2 Ch 101(Ch) 120 (Atkin LJ); In Re Russian Bank for Foreign Trade [1934] Ch 720 (Ch) 738 (Eve J).

95 The test is often applied in cases involving bank accounts or insurance policy (see The King $v$ Irvine A Lovitt and Others [1912] AC 212 (HL) 219 (Lord Robson)). Exceptionally, the court might apply both tests in the same case to determine the situs (see $F \& K$ Jabbour $v$ Custodian of Israeli Absentee Property [1954] 1 WLR 139).

96 Part 72 of the Civil Procedure Rules. For a detailed analysis, see TC Hartley, 'Jurisdiction in Conflict of Laws: Disclosure, Third-Party Debt and Freezing Orders’ (2010) 126 LQR 194, 207.

97 Société (n 81) [59]; Kuwait Oil Tanker Co SAK and another v Qabazard [2003] UKHL 31 [16]. However, some earlier authorities have seemed to suggest a lower threshold establishing jurisdiction against the garnishee (debtor) without having to consider whether a debt is situated in England (see SCF Finance Co Ltd v Masri and Another (No 3) [1987] QB 1028, 1044 (Leggatt J)).

98 Société (n 81) [36] (Lord Hoffmann).

100 Taurus Petroleum Ltd v State Oil [2015] EWCA Civ 835 [35] (Moore-Bick LJ).

101 Société (n 81) [26] (Lord Bingham of Cornhill). 
assignment and a claim to enforce a third-party debt order or the like, eg, an attachment order derived from a foreign State, as in Five Star (No 2). The factual situation in that case could have given rise to a claim between the cargo owners as the judgment creditor (C2) and RZB as the assignee (A1), if the cargo owners had phrased their submissions in that way. There would have been two possible outcomes.

In the Five Star (No 2) case, the judgment creditor did not contest their rights in France, where the orders were granted. The reason, perhaps, was that they had only obtained provisional attachment orders, and the proceedings in France were stayed to await the result of the English proceedings. Here lies another positive effect of a comprehensive EU regime that also harmonises international jurisdiction: it reduces the chances of encountering choice-of-law difficulties. If, however, the judgment creditor had obtained the final orders, there would have been no need to join the English proceedings, since they could have enforced their rights over the French insurers in France. In the meantime, the assignee, RZB, might contest its rights to the assigned policy in a French court based on declarations successfully obtained from an English court. The French court would then face the question of whose claim takes priority. Currently, the matter would be decided by reference to French private international law rules, as the matter is not covered by Article 14 of Rome I.

If the issue were phrased as a matter of priority, the court would probably examine the law of the situs as a preliminary question when deciding whether a foreign debt order is enforceable regardless of the competing voluntary assignment. It is suggested in Deutsche Schachtbau v SIT Co Ltd that one criterion for enforcing such an order is that the garnishee order should be rendered at the situs of the debt. ${ }^{102}$ Another requirement, suggested in Rossano v Manufacturers' Life Insurance Co, is that the foreign court should, by the law of the situs, have jurisdiction over the judicial creditor, debtor and third-party. ${ }^{103}$ Assuming that these requirements are fulfilled, the court would face two good claims of an assignment, both of which are valid according to their respective governing laws, and unfortunately, the priority between them remains unclear.

Overall, the law of the situs should be considered when the debt is foreign. Given that the function of a third-party debt order is to extinguish a debt, a court should evaluate the potential risks of 'double jeopardy' that the debtor/thirdparty might face if a court of the situs were to render a similar decision. An English court will first consider whether an order relating to a foreign debt will be enforced by reference to lex situs and then consider whether a foreign attachment order can be obtained under that law. In both cases,

102 Deutsche Schachtbau-und Tiefbohr-Gesellschaft MBH v Shell International Petroleum Co Ltd [1990] 1 AC 295 (HL) 354 (Lord Goff of Chieveley).

103 [1963] 2 QB 352, 382 (McNair J). 
English courts have discretion regarding the extent to which a foreign law is considered. ${ }^{104}$ What would be the result if a court had to determine the priority between a voluntary assignment and a third-party debt order remains uncertain.

\section{THE WAY FORWARD}

The picture is now complete. When a domestic court encounters a cross-border assignment, the issue of the choice-of-law is unproblematic if only primary parties are concerned, regardless of whether an assignment takes place voluntarily or involuntarily. The issue only becomes troublesome in two situations in which extended parties have competing claims against primary parties: first, in the case of consecutive voluntary assignments and, second, in the case of a voluntary assignment taking place against the background of an involuntary assignment. Under both circumstances, the choice-of-law rules lack clarity. It is argued that taking an economic perspective of debt transactions and an interest-analysis theory of the choice-of-law can shed some light and help identify a new solution to the problem.

\section{A. The Use Value and Exchange Value of Debts}

From an economic perspective, debt has a dual nature as an exchangeable commodity that can be utilised to satisfy existing monetary obligations. A distinction should be made between two aspects of the value in debts: use value and exchange value. ${ }^{105}$ The use value of a debt, also referred to as the nominal value, ${ }^{106}$ is the fact that the creditor can recover a certain sum from the debtor. To realise the use value is to extinguish the debt. The exchange value of a debt, on the other hand, is that the creditor can trade the debt via an assignment to others, usually at a discounted price, ${ }^{107}$ and to whom a right to recover the nominal value of the assigned debt is transferred. ${ }^{108}$ Exploiting the exchange value does not extinguish debt. The use value, or nominal value, is

\footnotetext{
104 Société (n 81) [26] (Lord Bingham of Cornhill).

105 The distinction between 'value in use' and 'value in exchange' is observed as different meanings of the word 'value' in economics scholarship (see A Smith, An Inquiry into the Nature and Causes of the Wealth of Nations (Electric Book Co 2001) 48). It is also adopted and further recaptured by Karl Marx to formulate the theoretic basis for his model of political economy (see K Marx, Capital: A Critique of Political Economy, vol 1 (Penguin 1990) 126-30). Professor Fentiman also noted a difference between asset value and transaction value in his discussion on assignment (see R Fentiman, 'Trading Debts Across Borders: A European Solution?' (2010) 17 Indiana Journal of Global Legal Studies 249-50).

106 Or 'redemption price' in the terminology of debt securities (Handbook on Securities Statistics (International Monetary Fund 2015) 2.11)

107 In theory, the 'issue price' can be at par, below par or above par. See ibid 2.10.

108 For a discussion of the dual nature of commodities, use value, and value in exchange under Marx's capitalism, see DK Foley, Understanding Capital: Marx's Economic Theory (Harvard University Press 1986) 13-14. For a practical guide to understanding market value and nominal value, see Handbook on Securities Statistics (Bank for International Settlements 2009) Annex 3.
} 
the fundamental feature of a debt, without which a debt lacks market value. It is fixed when debt is created, whereas the exchange value fluctuates as the market situation changes.

Looking at the two types of assignment on the basis of this distinction highlights an important difference. Regarding involuntary assignments, whether they are insolvency proceedings or third-party debt orders, the use value of the debt is the major concern. Voluntary assignments, on the other hand, seek to utilise the exchange value of the debt. The most significant advantage of trading debts worldwide in modern commercial transactions is not to transfer the face value of the debt but rather to acquire credit, security, or finance in return for it. ${ }^{109}$ When a debt is transacted, it is not automatically extinguished; instead, it remains transferable by and to subsequent parties. Imagine a case in which a debt has been assigned successively until it reaches the final title holder, who eventually receives repayment from the debtor. Although the entitlements obtained by the final holder may not exceed the use value of the debt, the overall profits conferred to all parties involved in previous assignments may be immense, perhaps many times the face value of the debt itself. Compared to other tangibles that are normally transacted upon delivery, debts as pure intangibles are a ready medium for quick finance.

It is also helpful to reflect on the three choice-of-law theories that have been mentioned in relation to cross-border assignments. First, the law governing the debt (or the legal event to which the debt relates) determines its essential features, encompassing both its use value and its exchange value. Second, the law of the situs highlights the aspect of use value because it engages the place where the debt is finally recoverable and enforceable against the debtor. It explains the relevance of the situs and the lex situs in involuntary assignments since both insolvency and judgment creditors seek to enforce debts. Third, the law governing voluntary assignments, which is usually chosen by the parties, reflects the exploitation of the exchange value of debts as an important trading commodity. This is particularly true when an assignee intends to hold the assigned debt for only a short time before trading it via another assignment.

From a domestic law perspective, the above distinction may not always be recognised. For example, the difference between use value and exchange value (also phrased as 'time value') has been somewhat controversial in the English domestic law of restitution. The leading authorities, especially Sempra Metals Ltd $v$ IRC and Littlewoods $v$ HMRC, seem to make no substantial distinction between the 'use value' and 'time value' of money. ${ }^{110}$ Both cases were concerned with claims for restitution arising out of the overpayment or wrongful payment of tax, in which the claimants

109 See Fentiman (n 105) 248-9.

110 See Sempra Metals Ltd (formerly Metallgesellschaft Ltd) v Inland Revenue Commissioners and another [2007] UKHL 34 [101]; Littlewoods Ltd and others v Revenue and Customs Commissioners [2017] UKSC 70 [30]. 
sought to recover interest measured by the 'time value' of money. It should be noted that the context under which two values of debt are considered in both cases is different from that of assignment, in that the former concerns compensation which arises from an existing legal dispute while the latter focuses more on ex-ante business planning.

The distinction between use value and exchange value is perhaps more significant in elucidating the different functions of voluntary and involuntary assignments than it is in the subsequent calculation of legal remedies once a dispute has arisen. For example, if a debt is $£ 100$, then its use value always remains $£ 100$, and it can be collected once it is due. However, the creditor can also choose to assign the debt for $£ 80$ and receive money before the maturity date. The exchange value thus fluctuates over time and will be fixed only when the debt is traded. In cases of restitution, the real question concerns the face value of the owed debt, which raises further questions about whether those enriched should be liable to pay interest, whether it is simple or compound interest, etc. ${ }^{111}$ In summary, this article suggests that the use value/exchange value discourse is helpful not in the calculation of a debt but rather in resolving choice-of-law issues. Choice-of-law rules should be constructed based on the understanding that a debt exhibits different properties when it is transacted differently. The old saying 'A bird in the hand is worth two in the bush' is a perfect explanation of the economic importance of exchange value compared with use value.

\section{B. The Modified Interest-Analysis Theory}

From a methodological perspective, distinguishing the contractual and proprietary aspects of assignments reflects a multilateralist approach to the choice-of-law, which derives from Friedrich von Savigny's seat theory. ${ }^{112}$ The primary task of methodological multilateralism is to consider the legal nature of a dispute and to designate the applicable law accordingly. The problem with this approach is that it assumes that similar classification results are attainable across jurisdictions; hence, the same choice-of-law rules would be applied to achieve a uniformity of results. However, when domestic laws are conceptually inconsistent in their treatment of assignments, it is impractical to expect national differences to be eliminated very rapidly.

111 For a detailed discussion, see M Hsiao, 'Liability to Pay Interest: Use Value and Time Value' [2018] LMCLQ 477, 479-81.

112 Briefly, this is that the choice-of-law question is to 'discover for every legal relation (case) that legal territory to which, in its proper nature, it belongs or is subject (in which it has its seat)' (FK von Savigny, Private International Law. A Treatise on the Conflict of Laws: And the Limits of Their Operation in Respect of Place and Time (William Guthrie tr, T \& T Clark 1869) 133). It proposes that legal relations should be divided into different families, personal status, property, contract, and family, and proceeds to select one nexus, for example, situs, as the connecting factor (see at 140). 
Therefore, a uniform substantive law understanding of assignment, which is deemed the foundation of the multilateral approach, is absent. Following this approach would mean that the characterisation results vary across jurisdictions. Since characterisation as the starting point is problematic, the ideals of multilateralism that similar legal issues will be treated in a similar fashion regardless of where a dispute is litigated would therefore fail, as would the goal of achieving international judicial harmony.

This article argues that a modified interest-analysis approach offers a better means of building a consistent choice-of-law solution for the problems presented by cross-border assignments. Such an approach draws on methodological unilateralism, ${ }^{113}$ according to which conflict of laws is essentially about competing positive laws. The purpose of the choice-of-law is to identify the scope of application of the laws concerned. ${ }^{114}$ The interest-analysis theory propounded by Brainerd Currie argues that the choice-of-law is a functional tool for the implementation of State policy, and the central task of a court is to maximise the possibilities of applying the law of the forum, should the forum State have an interest in applying local rules to the case in hand. ${ }^{115}$ Although Currie's analysis was often criticised as too politically oriented and having the potential to disrupt a precedent-based system, interest-analysis theory has had a lasting influence and has found its place not only amongst its US successors ${ }^{116}$ but also in EU regulations, where it is usually clearly stated in terms of political goals, such as market integration. ${ }^{117}$

Rather than a forum-centred approach, this article argues for a modified interest-analysis that advocates a party-centred approach as the starting point for determining the choice-of-law. As suggested previously, parties engage in cross-border assignments for different purposes. Some are voluntarily entered into for the purposes of debt transactions, whereas others are involuntarily imposed for the purpose of settling outstanding obligations. According to

\footnotetext{
113 The first inventors of the unilateral approach were the statutists, who tried to determine the scope of positive laws by classifying legal norms into two categories: real and personal (see JH Bealt (tr), Bartolus on the Conflict of Laws (Harvard University Press 1914) 3). Contemporary authors in this camp include Walter W Cook, Brainerd Currie and David F Cavers. As the scope of this article is restricted, for a detailed discussion on the relevant theorists and commentators, see WW Cook, The Logical and Legal Bases of the Conflict of Laws (Harvard University Press 1942); B Currie, 'On the Displacement of the Law of the Forum' (1958) 58 ColumLRev 964; DF Cavers, The Choice of Law Process (University of Michigan Press 1965); S Symeonides, The American Choice-of-Law Revolution: Past, Present and Future (Martinus Nijhoff 2006).

114 B Currie, Selected Essays on the Conflict of Laws (Duke University Press 1963) 180-4.

115 SE Sterk, 'The Marginal Relevance of Choice of Law Theory' (1994) 142 UPaLRev 949, 954.

116 See L Brilmayer, Conflict of Laws: Foundations and Future Directions (Little, Brown and Co 1991) 143-230; L Kramer, 'Rethinking Choice of Law' (1990) 90 ColumLRev 277, 319-38.

117 See CA Whytock, 'Faith and Scepticism in Private International Law: Trust, Governance, Politics, and Foreign Judgments' [2014] ErasmusLRev 113, 123-4; J Meeusen, 'Instrumentalisation of Private International Law in the European Union: Towards a European Conflicts Revolution?' (2007) 9 European Journal of Migration and Law 287, 300.
} 
such an approach, the forum must analyse whether competing interests are being asserted by the different parties; if so, four considerations might guide courts' decision-making regarding whose interests should prevail. First, the obligations of the debtor should not be magnified because of a subsequent assignment. This means that certain matters concerning the debt—such as its attributes, formalities that need to be undertaken to make a direct claim against the debtor, ways of satisfying the debt, and assignability — should be governed by laws that are known to the debtor. Second, a stand-alone voluntary assignment should protect the expectations of both the assignee and the assignor. Third, since insolvency proceedings prioritise the preservation of the insolvent estate, the interests of general creditors, represented by insolvency administrators, could prevail over an assignee's interests acquired under a voluntary assignment. Fourth, in proceedings concerning a third-party debt order, the judgment creditor's interest in debt recovery may be secondary to the importance of safeguarding the debtor from being subject to excessive obligations. Hence, as a practical guide, the hierarchy of protected interests appears to be as follows:

- The interests of the debtor (D) with respect to understanding the features of the debts.

- The interests of insolvency administrators/judgment creditors (C2) in settling the debt.

- The interests of the assignees (A1's and A2's) with respect to the debt.

- The interests of the assignor (C1) to conduct autonomous debt transactions.

Notwithstanding the party-centred starting point, the outcome of a cross-border dispute will vary depending on the role of the court where a case is seised. For example, the forum in which an insolvency proceeding is commenced probably has an incentive to preserve the chances of realising a debt rather than of maintaining its transferability, whereas a forum considering a case concerning the priority of competing voluntary assignments may favour the opposite. Realistically, the parties can be expected to choose the forum that appears to be the most favourable to them, and their manoeuvring for advantage when engaged in litigation remains a major variable for international justice. ${ }^{118}$ Therefore, when formulating generic guidance on the choice-of-law, it makes sense to frame it upon the factual circumstances of the particular dispute, who are the litigating parties and the grounds on which the claim is based.

\footnotetext{
118 In a sense, forum shopping remains an essential strategy in international litigation (see G McCormack, 'Bankruptcy Forum Shopping: The UK and US as Venues of Choice for Foreign Companies' (2014) 63 ICLQ 815).
} 


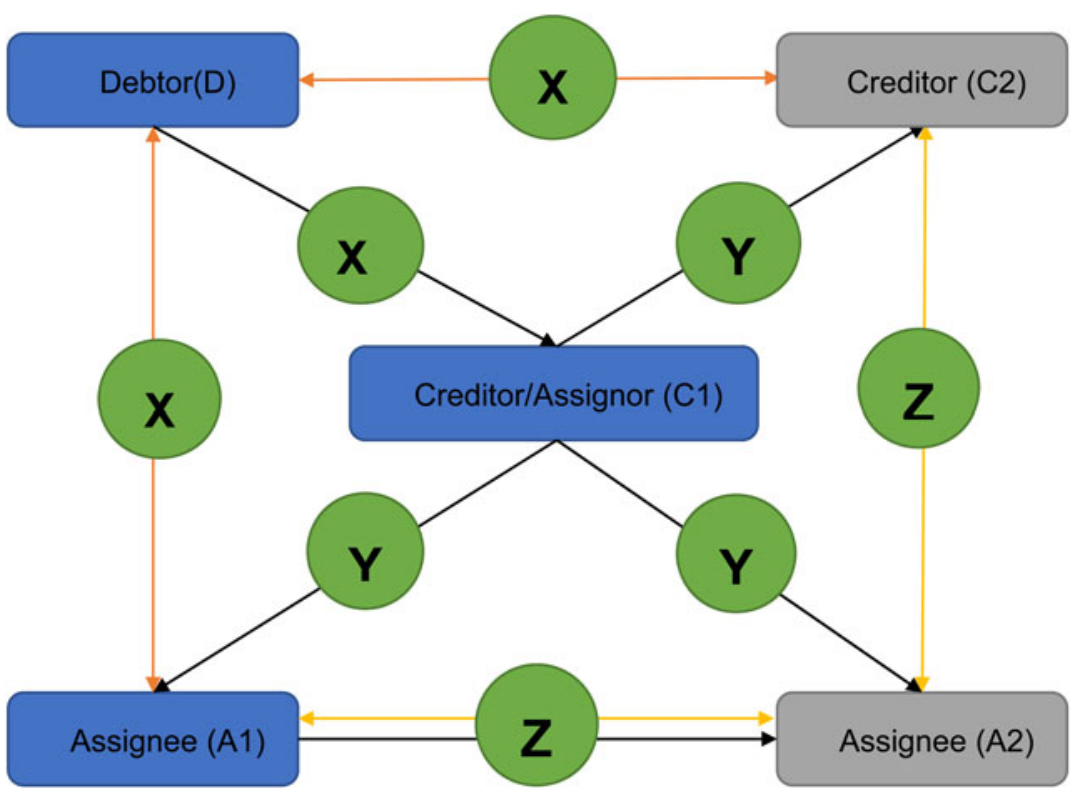

FIgURE 2. Configuration of the choice-of-law

$\mathrm{X}$ : the law governing the underlying debt. Y: the law governing the legal event that gives rise to the assignment. In the case of a voluntary assignment, this is determined by the contractual choice-of-law rules. In the case of an involuntary assignment, this is determined by either the lex concursus or the lex fori. Z: the law governing the last legal event is normally applied with determinative effect.

\section{The Choice-of-Law Framework}

Against this background, it is helpful to re-examine the configuration of the choice-of-law for cross-border assignments. The proposed solution takes into account time-related aspects of an assignment within a party-centred interest-analysis. It involves a chronological examination of relevant legal events, examines the scope of the laws concerned and designates choice-of-law rules that reflect the hierarchical protection of relevant interests.

\section{Among primary parties}

The primary parties are the assignor/creditor (C1), debtor (D) and assignee (A1). The first legal event is that under which $\mathrm{C} 1$ and $\mathrm{D}$ have established a monetary obligation between themselves. Assuming this event is governed by law X, D's obligations should not be altered or worsened by a successive assignment without D's agreement. Law X should therefore determine matters that are crucial to D's existing understanding of the repayment, for 
example, features of the debt (such as its face value, the currency of payment, maturity date, etc), assignability, and formalities for obtaining discharge, etc.

The second legal event is the assignment between $\mathrm{C} 1$ and A1, and the law governing the assignment, law Y, should determine the relationship between them. If the assignment is voluntary, contractual choice-of-law rules should determine the governing law, which will most likely be agreed upon by A1 and $\mathrm{C} 1$. If insolvency proceedings are involved, the powers of A1 as the receivers are determined by the law governing the insolvency, the lex concursus. ${ }^{119}$ If it is a third-party debt order or the like, A1's rights as the judgment creditor are determined by the law of the forum where the order is granted. ${ }^{120}$

\section{Between $C 2$ and $A 1$}

If an involuntary assignment takes place in the context of an existing voluntary assignment, the question will arise as to who has the better claim to the assigned debt as between A1 and C2. ${ }^{121}$

First, a preliminary question needs to be asked regarding whether there is a valid assignment between $\mathrm{A} 1$ and $\mathrm{C} 1$, according to law $\mathrm{Y}$. If there is, the principal question needs to be phrased differently depending on which of the two types of proceedings is at issue.

In insolvency proceedings, the question is whether C2 is capable of exercising rights against $\mathrm{D}$ with respect to the debt upon the opening of the proceedings. A distinction should be made between the different roles C2 plays. As a general assignee of $\mathrm{C} 1, \mathrm{C} 2$ should be bound by any liabilities that also bind $\mathrm{C} 1$. This situation has also been referred to as $\mathrm{C} 2$ 'stepping into the shoes' of $\mathrm{C} 1$. If $\mathrm{C} 1$ has validly assigned the entirety of the debt to A1 under law $\mathrm{Y}$, the debt then falls outside the scope of C1's insolvency estate, leaving C2 with no better claim than A1. If, however, $\mathrm{C} 2$ is claiming overriding rights against the debt despite a valid assignment, $\mathrm{C} 2$ is now acting on behalf of C1's insolvency creditors who rank higher on the protection list of insolvency law. On the grounds provided by the lex concursus, C2 could effectively challenge A1's rights to the debt, usually under transaction avoidance rules or the like. Therefore, whether C2's claim could prevail over that of A1 depends largely on the law of the place where the proceedings are opened, Z, but the grounds for winning a claim are limited. ${ }^{122}$

119 This refers only to the situation of stand-alone insolvency proceedings.

120 Similarly, this refers only to the situation of a standalone third-party debt order.

121 This refers to C1's insolvency administrators or judgment creditor.

122 The solution proposed is different from the earlier discussion in which EU law is considered. Because the EU scheme has a modified interest hierarchy of attaching greater importance to cross-border legal harmonisation and juridical cooperation, the law of a Member State should have stronger effects than the law of a third State. 
Regarding a third-party debt order, the question is whether $\mathrm{C} 2$ should be able to enforce rights against D notwithstanding the voluntary assignment, since the protection of the debtor's interests should be prioritised. If a court is to consider whether to issue an order on C2's behalf despite the competing claim from A1, the law of the forum will apply to determine whether such an order would be unjust to D. When doing so, the forum might consider the lex situs, but the extent to which such an analysis is conducted remains a matter to be determined by the lex fori, law $\mathrm{Z}$ in this example. If a court is to adjudicate which of the competing claims should prevail, the issue of the choice-of-law could be fairly straightforward, since it is very likely that the case will be brought before a court at the place of the debtor's residence. The potential applicable laws, the lex fori and lex situs, are therefore the same. Once again, law $\mathrm{Z}$ is applied with determinative effect.

\section{Between $A 1$ and $A 2$}

The most complex situation is that of two competing voluntary assignments. Choice-of-law rules governing voluntary assignments should strive to fulfil contractual parties' expectations concerning the validity of an assignment and to answer who should have the stronger claim if a debt has been successfully assigned multiple times.

The issue of the priority between A1 and A2 can be analysed in three steps. Rights established first in time generally outrank those established later. Regarding the first assignment between $\mathrm{C} 1$ and $\mathrm{A} 1$, the law governing their contract, law Y, should determine matters such as the formalities with which A1 must comply, the time when an assignment becomes effective and, most importantly, whether $\mathrm{C} 1$ retains the right to make a further assignment. ${ }^{123}$ Presumably, if under Y, A1 must fulfil a strict range of formalities to complete the transaction, it is more likely that A1's claim would survive a successive assignment.

Second, matters determined by law $\mathrm{Y}$ should generally be binding on $\mathrm{C} 1$ and determine his or her ability to make a second assignment. If, under law Y, C1 is able to make another assignment, then the law governing the assignment between $\mathrm{C} 1$ and $\mathrm{A} 2$, law $\mathrm{Z}$, should also apply to matters between them. In such a situation, as between $\mathrm{A} 1$ and $\mathrm{A} 2$, the first to obtain an effective assignment under the applicable governing law should, in principle, have priority over the other.

Third, if $\mathrm{C} 1$ is not able to make a subsequent assignment under law $\mathrm{Y}$, the question becomes whether A2 can acquire rights over the assigned debt from an unauthorised assignor, $\mathrm{C} 1$. This is determined by the law governing the second assignment, law $\mathrm{Z}$, if $\mathrm{Z}$ allows $\mathrm{A} 2$ to nonetheless acquire rights in respect of the debt under an unauthorised transaction, eg, provided A2 acts in

123 This usually happens when $\mathrm{C} 1$ assigns the debts as security rather than an outright transfer. 
accordance with the relevant rules on good faith acquisition. ${ }^{124}$ If the relevant requirements are satisfied, the second assignment is valid and overrides the first assignment. Therefore, depending on the content of law $\mathrm{Z}$, the law governing the last event may trump the effectiveness of the previous assignment. This analysis is only relevant when the dispute concerns the priority of claims between $\mathrm{A} 1$ and $\mathrm{A} 2{ }^{125}$ If $\mathrm{A} 1$ and $\mathrm{A} 2$ bring separate claims against $\mathrm{D}$, the question becomes one concerning primary parties, and the law governing the debt should be applicable.

Thus, many of the perceived priority conflicts can, to a large extent, be resolved by a nuanced analysis of the applicable scope of the governing laws for each assignment without introducing further connecting factors, such as the place of the assignor's residence as a meta-choice-of-law rule. Admittedly, applying this solution will not change the fact that a structural risk exists in the debt market system due to a lack of transparency, as it would be difficult for any assignee to investigate the exact status of the debt involved. ${ }^{126}$ However, from an economic perspective, it is such opacity that distinguishes debt from the equity market, making it an essential component of cross-border finance. ${ }^{127}$ It is, in a sense, a risk that the parties may have to bear.

\section{Merits of the framework}

Taken as a whole, the proposed framework sets a path that differs from the recent EU Commission proposal. The solution provided by the EU's working proposal is based on harmonising national private international laws by introducing an additional connecting factor, the assignor's habitual residence, as a constant and primary guide for resolving issues concerning extended parties. ${ }^{128}$ This approach has been criticised because choosing this as a connecting factor may not help simplify the existing choice-of-law system or be well supported. ${ }^{129}$ The momentum for this approach within the EU is

\footnotetext{
124 For a summary of comparative national rules in this regard, see Final Report (n 4) 37-8. For a recent empirical analysis on the change of national rules and legal culture, see G Dari-Mattiacci and C Guerriero, 'Law and Culture: A Theory of Comparative Variation in Bona Fide Purchase Rules' (2015) 35 OJLS 543.

125 An example of this type is when D has already obtained a good discharge by paying the debt to the court, and only A1 and A2 are in dispute for the paid sum.

126 The query is 'should it be open to the parties to an assignment to dictate third-party effects under a choice-of-law that will not be visible to third parties?' (Goode (n 15) 305).

127 See B Holmstrom, 'BIS Working Papers No 479 Understanding the Role of Debt in the Financial System' (2015) Bank for International Settlement 4-7.

128 European Parliament legislative resolution of 13 February 2019 on the proposal for a regulation on the law applicable to the third-party effects of assignments of claims (COM(2018) 0096-C8-0109/2018-2018/0044(COD)). Art 4 provides that the law of the country in which the assignor has its habitual residence applies as a general rule and specifically for a priority conflict between assignees of the same claim.

129 Labonté (n 15) 339-41.
} 
driven by the internal interest of creating a capital market union. ${ }^{130}$ However, the framework proposed here is designed for cases not covered by the EU regime and, more widely, non-EU Member States, where the national court has no interest in applying external policies. The proposal does not introduce a new choice-of-law theory for the purpose of harmonising choice-of-law rules but strives to achieve a better understanding of actual choice-of-law issues in cases of cross-border assignments. The choice-of-law solution is less complicated than one may imagine if a proper analytical framework is adopted. The present framework has the following merits.

First, it is comprehensive in scope and logically coherent. It identifies real choice-of-law problems arising from both involuntary and voluntary assignments facing a domestic court. Practically, it offers a solution that designates the applicable law by focusing on the parties to the dispute. Second, it is less intrusive upon national laws and can easily be adapted locally. The choice-of-law rules that become applicable are those that have been widely accepted in their respective areas, including the law governing the underlying debt, the law governing the assignment, lex concursus, and lex situs. The framework sets out their scope of operation within the framework of an interest-analysis. It can both accommodate differences in national laws concerning assignment and achieve a uniform private international law understanding without requiring material changes to national laws. The central focus concerns how to better conduct choice-of-law analyses rather than to suggest reforms to existing choice-of-law rules.

Third, this approach encourages the maximisation of party autonomy. The law governing the voluntary assignment, law Y, which usually leads to the law chosen by the contractual parties, will be given weight and become decisive in many cases. In fact, the oft-discussed assignor's habitual residence rule can also be incorporated into this model if parties are encouraged to choose it as the governing law. Fourth, as parties may be expected to choose the substantive law that best protects their interests in a cross-border assignment, applying this approach could encourage global selection of the best substantive rules. In the long run, it could help facilitate the unification of the substantive law of assignments. Fifth, the operation of this model reinforces the importance of distinguishing between the two different forms of value of a debt. The use value is related to the application of the lex concursus, lex situs, and law governing the debt, whereas the exchange value is utilised in voluntary debt transactions governed by their own proper law.

\footnotetext{
130 It is recognised that 'differences in the national treatment of third party effects of assignment of debt claims' could give rise to legal uncertainty that would frustrate cross-border investment and obstruct the building of a single capital market in the EU (see Commission, 'Action Plan on Building a Capital Markets Union' $\operatorname{COM(2015)} 468$ final, 23). Prompt actions and plans are targeting third-party effects of assignment of claims (see Commission, 'Capital Markets Union Accelerating Reform' COM(2016) 601 final, 10).
} 


\section{CONCLUSION}

The development of private international law in recent decades has resulted in great technicality and complexity. This is especially true of legal regimes in which national substantive laws differ significantly, such as in the case of cross-border assignments. This article argues that an openness to different national understandings of legal institutions is one of the foundational principles for private international law. The choice-of-law solution in this regard should be more practically oriented and should operate within a restrictive spectrum focused on those who are in need of it, ie, the parties concerned and the national courts.

Unlike many discussions that often result in a comparison of choice-of-law doctrines, this article calls for a structural rebuilding of the choice-of-law questions relevant for the assignment of debts. Drawing on the economic values of debts and interest-analysis theory, the proposed analytical framework reflects two main issues: the functional use of debt should be appreciated, and the importance of forum shopping should be accepted. The proposal is beneficial to three stakeholders.

First, parties who are voluntarily engaged in cross-border assignments, eg, assignors and assignees, are encouraged to actively plan their commercial activities by making good use of their choice-of-law clause and, if necessary, litigation strategies to maximise the commercial value of their debt transactions. They should not be limited to identifying applicable laws and complying with them but should seek to put themselves in a favourable position through a balancing of use value and exchange value of debts. Second, the interests of parties who are involuntarily involved in an assignment case, eg, debtors and creditors, are strongly safeguarded under this framework. Third, it fills the gaps in domestic private international law for national courts, especially when extended parties are in dispute. Furthermore, it does not require choosing one choice-of-law doctrine over another but only engaging in better choice-of-law analysis. Overall, the framework offers a straightforward solution that designates choice-of-law rules based on the status of the disputing parties and by delineating the different legal effects of relevant events. It does not conflict with the regulatory scheme that the EU is expected to adopt. It also provides useful guidance for countries such as the UK, where there is currently a gap in domestic private international law concerning cross-border assignment. 